Volume 9

$10-2015$

\title{
Unsettling Genocide Studies at the Eleventh Conference of the International Association of Genocide Scholars, July 16-19, 2014, Winnipeg-Canada
}

Andrew Woolford

University of Manitoba

Follow this and additional works at: https://digitalcommons.usf.edu/gsp

\section{Recommended Citation}

Woolford, Andrew (2015) "Unsettling Genocide Studies at the Eleventh Conference of the International Association of Genocide Scholars, July 16-19, 2014, Winnipeg-Canada," Genocide Studies and Prevention: An International Journal: Vol. 9: Iss. 2: 98-102.

DOI:

http://dx.doi.org/10.5038/1911-9933.9.2.1321

Available at: https://digitalcommons.usf.edu/gsp/vol9/iss2/10

This Conference Proceeding is brought to you for free and open access by the Open Access Journals at Digital Commons @ University of South Florida. It has been accepted for inclusion in Genocide Studies and Prevention: An International Journal by an authorized editor of Digital Commons @ University of South Florida. For more information, please contact digitalcommons@usf.edu. 


\section{Unsettling Genocide Studies at the Eleventh Conference of the International Association of Genocide Scholars, July 16-19, 2014, Winnipeg-Canada}

\section{Acknowledgements}

My thanks to Tricia Logan, Adam Muller, Donna Lee Frieze, Jeff Benvenuto, Daniel Feierstein. Melanie O'Brien, and David MacDonald for their comments on a previous version of this paper. My thanks to the Social Sciences and Humanities Research Council, the University of Manitoba, and Tourism Winnipeg for the funding they provided to make our conference possible. 


\title{
Unsettling Genocide Studies at the Eleventh Conference of the International Association of Genocide Scholars, July 16-19, 2014, Winnipeg-Canada
}

\author{
Andrew Woolford \\ University of Manitoba \\ Winnipeg, Manitoba, Canada
}

\begin{abstract}
What is the purpose of a genocide conference and in what ways might such a conference unsettle us and contribute to a broader decolonizing project, in genocide studies and beyond? This summary of the Eleventh Conference of the International Association of Genocide Scholars at the University of Manitoba in Winnipeg, Manitoba, Canada examines some of the disruptions and connections that arose and contributed to the vitality of our meetings.
\end{abstract}

Keywords: genocide studies, conference, settler-colonialism, Canada, Indigenous peoples

When Winnipeg was selected as host for the Eleventh Conference of the International Association of Genocide Scholars, it was an opportunity to showcase the intellectual vibrancy of the city and region to our visiting delegates. In Canada, Winnipeg is the butt of too many jokes. Depending on the season, it is portrayed as a land of unbearable cold ("Colder than Mars," read one recent headline), floods, and mosquitoes. Depending on the season, it is derided as Winterpeg or Waterpeg. To this extent, Winnipeg may seem the less-exotic conference option when bookended by meetings in Siena and Yerevan. But Winnipeg is also at the geographic centre of North America. It sits at the forks of the Red and Assiniboine Rivers, at the crossroads of the Anishinaabe, Métis, Cree, Dakota and Oji-Cree Nations. It is a historic meeting place of Indigenous peoples, and a most fitting site for our conference theme: Time, Movement, and Space: Genocide Studies and Indigenous Peoples. It is a space long marked by movements and interactions among peoples, including the destructive momentum of settler colonialism. Winnipeg is also a refugee center, meaning it attracts many newcomers who are fleeing oppression and human rights violations elsewhere. It is home to substantial Sudanese, Rwandan, Cambodian, Bangladeshi, Somalian, Sierra Leonian, Burmese, and other communities of individuals who have been forced to flee their homelands. As well, it has a large historic population of survivors of the Holocaust and other groups subjected to Nazi genocide.

But it is the settler colonial present that perhaps stands out most in the Winnipeg zeitgeist. This in large can be credited to Winnipeg's active Indigenous community. Theirs are the strongest voices opposed to a seemingly ever-ascendant settler colonialism. One goal of the conference organizers was to create opportunities for Indigenous scholars, leaders, and community members to contribute to and direct our discussions. This began prior to the conference by making sure that the conference was well-advertized on websites, listservs and through Facebook groups frequented by local Indigenous peoples. We were also fortunate that a reporter featured our conference in a local newspaper prior to our opening. Mary Agnes Welch framed her Winnipeg Free Press article around the question of genocide in Canada, and featured comments from several of our presenters, including Charlene Bearhead, Trina Cooper-Bolam, and David MacDonald. ${ }^{1}$ The article provoked debate on both the comments page and in the editorial section of the paper. Local independent historian Michael Melanson wrote a letter to express his concern that Canadian genocide scholars were distorting the meaning of genocide by straying from the definition contained within General Assembly Resolution 260, the Convention on the Prevention and Punishment of the Crime of Genocide (CPPCG, December 9 1948). My published response noted the multiple understandings of genocide possessed by IAGS members, and that we, as an association, do not uniformly agree on the definition of genocide. However, I also challenged his devotion to the UNGC without acknowledging the political and cultural context in which it was formed. As a scholar trained in critical criminology and critical socio-legal studies, I am often troubled by our tendency to obediently accept the force of law without questioning its often arbitrary and contingent foundations. ${ }^{2}$ In the decolonizing context of the Eleventh IAGS Conference, the settler colonial foundations of genocide law, as well as the Euro-settler epistemological and ontological assumptions that are entangled 
with much of our thinking about genocide were subject to pointed criticism by many of the Indigenous and non-Indigenous scholars who were present. Melanson, although not a participant in our conference, inadvertently exemplified one of the barriers to greater Indigenous participation in associations like ours: the violence that comes with an unwillingness to acknowledge different ways of seeing and knowing the world.

Such epistemological and ontological tensions would erupt into moments of contention during our conference sessions, but we also received encouragement to govern our discussions in a spirit of respect and right relations. On the first day of the conference, we travelled from Winnipeg to the Sagkeeng First Nation. Sagkeeng, formerly known as the Fort Alexander reserve, is an Anishinaabe community located on the east side of Lake Winnipeg, along the Winnipeg River. The community has a population of approximately 3300, many of whom either survived or are second and third generation Survivors of the Fort Alexander Residential School. This school was run from 1904 until 1970 by the Oblates of Mary Immaculate, an order of the Roman Catholic Church, and was located within the Sagkeeng community. Thus, unlike other residential schools, where children were removed far from their homes to be subjected to forced assimilation, most children from Sagkeeng were boarded within their community. But this proximity provided little comfort. The Fort Alexander students, who were also exposed to the cultural violence of forced assimilation, as well as high levels of physical and sexual victimization, often learned to resent their family members, who they could see beyond the gates and barbed wire going about their lives while the children were left to suffer therein. ${ }^{3}$

We had a rough start to this excursion. The buses sped by the designated meeting spot, and then one of the buses broke down. We therefore had to cut out a visit to some unmarked graves that hold the bodies of children who perished while at the residential school. After a brief moment of chaos, we managed to find rides for all of our scholars to Turtle Lodge, where a ceremony to welcome us to Sagkeeng territory waited. Anxiety levels were high (at least for the hapless organizer!), but all negative feelings were erased when we entered Turtle Lodge. The drums, the smell of the smudge, ${ }^{4}$ and the welcome song brought us into the Lodge's sacred space, where we were reminded of the resilience and persistence of Indigenous cultures, despite settler colonial efforts to destroy them. Elder David Courchene introduced IAGS delegates to Anishinaabe traditions and reminded us of the importance of our work and our shared responsibility to walk the right path, caring for each other and our shared planet. ${ }^{5}$

That night, IAGS scholars continued their education in Indigenous knowledges and approaches to justice. Felix Cardenas, the Viceminister of Decolonization for the Plurinational State of Bolivia spoke to us about his government's efforts to revolutionize their society in an anti-patriarchal and decolonizing fashion. His talk elicited a lengthy standing ovation. In the days subsequent to his keynote address, the Viceminister met with several local Indigenous leaders, making IAGS the site for information sharing on the topic of decolonization in the Western Hemisphere.

Also at the opening keynote, Ned Blackhawk, Western Shoshone Professor of History and American Studies at Yale University, challenged both the erasure of colonial violence in North American historiography and the prevalent presuppositions of the genocide studies approach to Indigenous experiences of destruction, reinforcing the need for genocide studies to take seriously the work emerging from the growing field of Indigenous studies.

In the next day's keynote address, Ho-Chunk professor of American Studies Amy Lonetree (University of California, Santa Cruz) discussed decolonizing practices within museums and how Indigenous peoples are increasingly pushing these institutions to "speak to hard truths in an effort to heal from unresolved historical grief." She noted how some museums, such as the Ziibiwing Centre in Michigan, do this well and in a manner that privileges Anishinaabe prophecies and oral tradition. This museum also does not shy away from naming genocide in relation to Anishinaabe experiences of settler colonialism, something that cannot be said with respect to Winnipeg's recently opened Canadian Museum for Human Rights or the United States National Museum of the American Indian.

On the conference's third day, Australian historian Tony Barta (La Trobe University) asked us to consider how we might "liberate genocide" so that the term no longer simply shuts down the conversation or becomes narrowed by reductionist legal interpretations. He presented conference 
goers with a powerful call to continue to advance genocide studies beyond narrow legalism and to bring forward approaches that do more to illuminate the past and present, including the settler colonial present.

Finally the conference featured several special panels at which we heard from representatives from the Canadian Museum for Human Rights and Commissioners Marie Wilson and Chief Wilton Littlechild of the Truth and Reconciliation Commission of Canada, as well as from residential school Survivor Theodore Fontaine, who noted of his experience at Fort Alexander Indian Residential School, "The biggest damage of Indian Residential Schools was the reluctance to admit you were an Indian."

It would be an impossible task to discuss all of the interesting papers presented at the conference in this short space. In my (albeit very biased) estimation these were some of the strongest papers ever assembled at an IAGS conference. The emerging scholars who are entering the field with such critical energy and insight particularly impressed me. Likewise, the Indigenous scholars who joined us for the conference, and hopefully will remain members of IAGS, brought the North American settler colonial context to the forefront. Many of these scholars raised important questions about practices of commemoration and truth-seeking as are currently taking place in Canada. Museum exhibits and repatriations, land dispossession, residential schools, and colonial archives were other topics under intense scrutiny. The discussion of these matters often became heated. It was not that we so much disagreed about the facts of the case, at least in the sessions I observed, although occasionally debates over the historical record arose. Instead, what animated these discussions was the interrogation of our very categories of meaning. The Eurocentric hegemony of terms such as reconciliation, and even genocide, was challenged, as session attendees were asked time and again to extend beyond their epistemological starting points and to consider other ways of understanding these terms we at times take for granted.

It was not only the topic of settler colonial genocide that generated heat at the conference, however. By all accounts the two presentations on the question of crimes against humanity committed by Israel were some of the most contested of the conference. In one particular case, the entire panel was locked in a lengthy debate; indeed, I had to later go in and disperse the crowd so subsequent sessions would not be delayed. In the aftermath of this panel, and others presented at the conference, I was asked about how certain papers that some found offensive were accepted to the conference. The simple answer is by a peer review process that involved evaluation of the proposed presentation by area experts, and this process did result in many rejections and several requirements that authors revise and resubmit their papers to meet accepted scholarly standards. But the evaluation committee was also bound by the principle of academic freedom not to try to shape the content of the submissions, since the human right to free speech is also at stake here. However, my own view on this matter, which extends beyond but was not included in the procedural criteria that directed the work of the evaluation committee, is that we as genocide scholars cannot, and should not, expect our conferences to be free of moments of discomfort, passion, anger, or emotion. The issues we discuss are both personal and political. They are situated in our daily lives, embedded in our various existences. Our commitments can make us powerful advocates, but can also blind to other points of view.

Indeed, for me, some of the most powerful moments of the conference came when I felt most uncomfortable, such as when powerful Indigenous scholars like Tamara Starblanket, Audra Simpson, Ned Blackhawk, Jeremy Patzer, and others highlighted land dispossession as a fundamental component of North American genocide, or when Kristin Burnett and Travis Hay questioned the dominating and sometimes dismissive role of settler colonial scholars in the study of Indigenous genocide. In these instances, I had no recourse but to confront and question myself as a settler colonial genocide scholar, but also my connection to this place I feel to be home, and yet is only my home only as a result of acts of extreme violence and erasure.

The study of genocide should not be easy. Nor should our conferences be comfortable affairs. They must be unsettling, since the nature of our work is unsettling. In the Canadian context, such unsettling means confronting the privilege and power bestowed upon many of us as a result of settler colonial relations. As an example, we were fortunate to have in attendance at our conference Chief Erwin Redsky from the Shoal Lake First Nation. Shoal Lake is also the source for Winnipeg's 
water. We conference goers enjoyed many glasses of some of the purest tap water available in North America while going about our affairs. But for this to be possible, the Shoal Lake First Nation had to be displaced from their original village site to a man-made island where, in the most unfortunate of ironies, they have to boil water in order to have clean drinking water. ${ }^{6}$ At the same time, we met and discussed group destruction at a University that in an earlier era trained many teachers that worked in a residential schooling system that sought to destroy Indigenous cultures. ${ }^{7}$ Recognizing these everyday moments of destruction unsettles us by forcing us to see our own location within a genocidal set of relations. ${ }^{8}$ As genocide scholars, we do not inhabit a space outside of the destruction we study; it is every-present in our day-to-day lives, and we are thankful to the Indigenous Survivors, scholars, and leaders who reminded us of this fact during the four days of our conference.

While I know of at least a few genocide scholars question IAGS hosting its conferences around specific genocides or commemorative events and thereby contributing to a "hierarchy of genocides", I could not imagine hosting an apolitical conference in Winnipeg. To host the conference in Canada and not involve Indigenous Survivors, leaders, and scholars - or not to confront Canada's history - would itself be a political act. The silence would speak volumes. So we met, and we made each other feel uncomfortable at times, and we were aghast or enlightened, enraged or inspired, but hopefully never indifferent or bored.

Perhaps we even began the process of decolonizing genocide studies. Although the process of decolonization is a long one, that may take seven generations, we as an association received a glimpse of what it might mean to decolonize ourselves. It is not merely a matter of having settler scholars like myself trying to translate insights from Indigenous epistemologies into the genocide studies canon..$^{9}$ It is more the need to create spaces where Indigenous scholars can come to the forefront and feel there is room for other ways of seeing, knowing, studying, and being amidst genocide scholarship.

In the end, a good genocide conference takes an emotional toll. Although at times I fear that I am becoming desensitized to violence through my study of genocide, there are always moments at IAGS conferences where I find myself emotionally connected to those who have suffered the toll of genocide. In Winnipeg, the affective power of our research hit me most when my friend Theodore Fontaine, who later shared with us the physical, sexual, cultural and spiritual violence he suffered at the Fort Alexander Indian Residential School, read a short story written by another friend, Rwandan genocide survivor Rafiki Ubaldo. This was part of our twenty-year commemoration of the genocide in Rwanda. We invited Rafiki to read his prize-winning short story for this event, but unfortunately he was unable to join us in Winnipeg. In his wisdom, he suggested that we ask a residential school Survivor to read the story. Theodore did a remarkable job and the effect was profound. As he read, "Listen to me. You will say nothing. What you saw is now between you, your father and me. I don't care what you think. I am telling you, you will say nothing," continents connected and divergent experiences of attempted group destruction overlapped as the shared experience of feeling silenced came forward. Decolonizing IAGS, as we sought to do in Winnipeg, and should continue to do in all our venues, means that Indigenous peoples - scholars, Elders, Survivors, leaders, women, and young people - will not experience our conferences and journals as silencing spaces.

It was a privilege to be part of team that organized this conference, which has left me with so many moments that still resonate with my life and research. My thanks to Adam Muller, Natalia Ilyniak, Donna Lee Frieze, Daniel Feierstein, Rafiki Ubaldo, Borislava Monojlovic, Tricia Logan, Helen Fallding, Karen Busby, Mark Meuwese, Kimberley Ducey, Regine King, Douglas IrvinErickson, and Steven Cooke, as well as all of our sponsors, participants, keynotes, special guests, and student assistants for their assistance in making this event possible.

\section{Acknowledgments}

My thanks to Tricia Logan, Adam Muller, Donna Lee Frieze, Jeff Benvenuto, Daniel Feierstein. Melanie O'Brien, and David MacDonald for their comments on a previous version of this paper. My thanks to the Social Sciences and Humanities Research Council, the University of Manitoba, and Tourism Winnipeg for the funding they provided to make our conference possible. 


\section{Endnotes}

1 See Mary Agnes Welch, The genocide test, Winnipeg Free Press, July 12, 2014, http://www.winnipegfreepress. com/breakingnews/the-genocide-test-266849891.html; Michael Melanson, Canadian policies don't meet the genocide test, Winnipeg Free Press, July 17, 2014, http://www.winnipegfreepress.com/opinion/analysis/ canadian--policies--dont-meet-genocide-test-267286851.html; Andrew Woolford, Genocides distinct, complex, Winnipeg Free Press, July 18, 2014, http://www.winnipegfreepress.com/opinion/letters to the editor/have-your-say-267613581.html

2 On the force of law see Jacques Derrida's seminal essay "Force of Law: The 'Mystical Foundation of Authority"' in D. Cornell, M. Rosenfeld, and D.G. Carlson (Eds.) Deconstruction and the Possibility of Justice (London: Routledge, 1992), as well as Pierre Bourdieu's essay by the same name, "The Force of Law: Toward a Sociology of the Juridical Field" Hastings Law Journal 38 (1987): 805- 853.

3 For more on Fort Alexander Indian Residential School, see Theodore Fontaine, Broken Circle: The Dark Legacy of Indian Residential Schools, A Memoir (Victoria: Heritage House, 2010); Phil Fontaine, "We are all Born Innocent." In Residential Schools: The Stolen Years, ed. Linda Jaine, 51-68 (Saskatoon: University Extension Press, 1993); Craig Charbonneau Fontaine, ed. Speaking of Sagkeeng. Trans. Allan Fontaine (Sagkeeng First Nation: KaKineepahwitamawat Association, 2006); Andrew Woolford, “Discipline, Territory, and the Colonial Mesh: Boarding/Residential Schools in the U.S. and Canada." In Colonial Genocide in Indigenous North America, eds. Andrew Woolford, Jeff Benvenuto, and Alexander Laban Hinton. Durham, NC: Duke University Press.

4 A smudge is a bundle of medicines or, as settlers might term them, herbs. In our case, the herb was sage, which was lit from the sacred fire to help purify body, mind and spirit.

5 See "Genocide scholars visit Sagkeeng to talk residential schools", Aboriginal Peoples Television Network: http://aptn.ca/news/2014/07/17/genocide-scholars-visit-sagkeeng-first-nation-talk-residential-schools/

6 See Shoal Lake's website for further information: $\underline{\text { http://www.sl40.ca/about.htm }}$

7 See the University of Manitoba apology made before the Truth and Reconciliation Commission of Canada: https://umanitoba.ca/about/media/StatementOfApology.pdf

8 Tony Barta's path-breaking work on relations of genocide is notable here. Tony Barta, "Relations of Genocide: Land and Lives in the Colonization of Australia." In Genocide and the Modern Age: Etiology and Case Studies of Mass Death, edited by I. Wallimann and M. N. Dobkowski, 237-52 (Syracuse, NY: Syracuse University Press, 1987).

9 As I attempted to do in Andrew Woolford, "Ontological Destruction: Genocide and Aboriginal Peoples in Canada." Genocide Studies and Prevention: An International Journal 4, no. 1, April (2009): 81-97. 